\title{
Alterations of store-operated calcium entry and cyclopiazonic acid-induced endothelium-derived relaxations in aging rat thoracic aorta
}

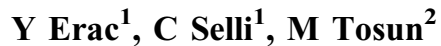 \\ ${ }^{1}$ Department of Pharmacology, Faculty of Pharmacy, Ege University, Izmir, Turkey \\ ${ }^{2}$ Department of Pharmacology, School of Medicine, Izmir University of Economics, Izmir, Turkey
}

Received: July 6, 2015

Accepted: March 15, 2016

\begin{abstract}
The purpose of our study was to investigate whether endothelium-derived relaxations induced by store depletion are altered in aging rat thoracic aorta. Vascular responses were measured in aortic segments isolated from young (2-4 month) and old (20-24 month) male Sprague-Dawley rats. In phenylephrine-contracted intact tissues, receptormediated and receptor-independent endothelium-derived relaxations were induced by acetylcholine (ACh) and sarcoplasmic/endoplasmic reticulum $\mathrm{Ca}^{2+}$ ATPase (SERCA) blocker cyclopiazonic acid (CPA), respectively. In addition, CPA-induced changes in intracellular calcium levels were monitored in fura-2-loaded endotheliumdenuded tissues. Real-time quantitative reverse transcription polymerase chain reaction and western blot analysis were performed to determine the transient receptor potential canonical (TRPC) $4 \mathrm{mRNA}$ and protein levels. Endothelial TRPC4 mRNA levels were apparently decreased in aging rats. Immunoblot analysis showed that TRPC4 protein levels significantly decreased in intact aorta from 20- to 24-month-old rats compared to that from 2- to 4month-old rats. ACh- and CPA-induced endothelium-dependent relaxations decreased in old rat aorta without any change in direct vasodilation induced by sodium nitroprusside. Store-operated $\mathrm{Ca}^{2+}$ entry (SOCE) induced by CPA was significantly decreased, whereas sarcoplasmic reticulum $\mathrm{Ca}^{2+}$ release was unaffected in endothelium-denuded aging rat aorta. In conclusion, TRPC4 downregulation could be associated with decreased endothelium-dependent vasorelaxations. As endothelial nitric oxide synthase is activated by SOCE-induced caveolar internalization, tracking the expression levels of SERCA, ion channels, and/or associated proteins involved in SOCE would lead to the development of novel therapeutics for age-related vasospastic disorders with dysfunctional endothelium.
\end{abstract}

Keywords: aging, vascular responses, SOCE, endothelial dysfunction, TRPC

\section{Introduction}

Aging is a major risk factor for the development of various cardiovascular diseases, such as atherosclerosis, hypertension, heart failure, and ischaemic heart disease. Several molecular, structural, and functional age-related alterations in cardiovascular system have been reported (59). Among these, several pathophysiological changes including endothelial dysfunction, vascular inflammation and reactivity changes, wall thickening, and arterial stiffening were observed during vascular aging (31). Age-related changes in responses to agonists such as noradrenaline and endothelin-1 (5) and in endothelium-dependent relaxations have been shown earlier $(8,14,37,38)$. Effects of aging in $\mathrm{Ca}^{2+}$ homeostasis and signaling pathways have also been implicated in several cardiovascular diseases $(4,13,16)$. Physiological processes in vascular smooth muscle are mainly regulated by the changes in spacio-temporal

Corresponding author: Professor Dr. Metiner Tosun, $\mathrm{PhD}$

Department of Pharmacology, School of Medicine, Izmir University of Economics

Sakarya Cad. 156, 35330 Izmir, Turkey

Phone: +90 232488 9843; Fax: +90 232279 2626; E-mail: metiner.tosun@izmirekonomi.edu.tr 
cytosolic $\mathrm{Ca}^{2+}$ levels $\left(\left[\mathrm{Ca}^{2+}\right]_{\mathrm{i}}\right)$; therefore, it is essential to delineate the changes that affect different $\mathrm{Ca}^{2+}$ entry mechanisms during aging.

Vascular reactivity is mainly dependent on $\left[\mathrm{Ca}^{2+}\right]_{\mathrm{i}}$ that is controlled by $\mathrm{Ca}^{2+}$ channels on plasmalemma and sarcoplasmic reticulum (SR) membrane $(15,33)$. Store-operated $\mathrm{Ca}^{2+}$ entry (SOCE) activated by SR depletion also contributes to regulation of $\left[\mathrm{Ca}^{2+}\right]_{\mathrm{i}}$. Depletion of intracellular $\mathrm{Ca}^{2+}$ stores activates $\mathrm{Ca}^{2+}$ influx across the plasma membrane via store-operated $\mathrm{Ca}^{2+}$ channels (SOCCs) (43). Activation of G-protein-coupled receptors such as G-proteincoupled acetylcholine (ACh) receptors also mediates SOCE by depleting SRs via inositol-1,4,5trisphosphate $\left(\mathrm{IP}_{3}\right)$-induced $\mathrm{Ca}^{2+}$ release or sarcoplasmic/endoplasmic reticulum $\mathrm{Ca}^{2+}$ ATPase (SERCA) inhibition by cyclopiazonic acid (CPA) or thapsigargin $(28,30,40,53)$. Both ACh and CPA increase $\left[\mathrm{Ca}^{2+}\right]_{i}$ through SOCE in endothelial cells yielding nitric oxide (NO) production that eventually leads to vascular smooth muscle relaxation $(34,39)$. CPA also induces endothelium-dependent vasorelaxations in intact rat aorta (44). On the other hand, exogenous NO donor, sodium nitroprusside (SNP) directly induces vascular smooth muscle relaxation through the activation of guanylate cyclase (GC) elevating cyclic guanosine monophosphate (cGMP) levels (12).

SOCE plays important roles in vasculature including endothelial proliferation, vascular tone and remodeling, and vascular smooth muscle cell migration and proliferation $(1,2,7,36,42,47)$. In addition, SOCCs have been shown to be associated with several cardiovascular diseases, such as idiopathic pulmonary hypertension, hypoxic pulmonary vasoconstriction, cardiac hypertrophy, aneurysm, and arrhythmia $(26,61)$. Although SOCE was downregulated in skeletal muscle of aging mice $(9,54)$, there is no report about age-dependent changes in SOCE function and capacity in vascular smooth muscle cells. Among the members of the transient receptor potential canonical (TRPC) protein family, TRPC1, TRPC3, and TRPC4 have been suggested to be the molecular components of SOCCs (3). TRPC1 contributes to SOCE by interacting with the basic components of SOCE, stromal interaction molecule (STIM1), and Orai1 (10). TRPC1 and TRPC6 are the most predominant members of TRPC ion channels expressed in vascular smooth muscle (17). Abundantly expressed in vascular endothelial cells, TRPC1 mediates SOC activity in endothelial cells by forming heteromultimeric channels with TRPC4 $(34,49,50)$. Furthermore, caveolar scaffolding protein caveolin-1 (Cav-1) has been suggested to regulate SOCE by binding to TRPC1 (35). On the other hand, Cav-1 directly interacts with endothelial nitric oxide synthase (eNOS) via its scaffolding domain (aa 89-101) $(21,29)$ and Cav-1 knock-out studies confirm the negative role of Cav-1 on eNOS (46).

In the present study, we investigated whether CPA-induced endothelial relaxations change during aging. For this purpose, receptor-dependent (ACh-mediated) and receptor-independent (CPA-mediated) endothelial relaxations were evaluated both in intact young and old rat aorta. Furthermore, SOCE-associated $\mathrm{Ca}^{2+}$ dynamics in endothelium-denuded vessels were also monitored. Delineating the involvement of SOCE in vasoconstriction/relaxation may be essential for the development of effective treatment strategies for age-related vascular disorders.

\section{Materials and Methods}

\section{Animals}

All experiments were approved by the Institution's Committee on Animal Use in Research and Education, Ege University, and Bilkent University. Rats (Sprague-Dawley, male, $n=20$ ) were maintained in appropriate conditions with ad libitum access to food and water, standard 
temperature and humidity, and a 12-h light/dark cycle. Rats were longitudinally aged and tested at two age intervals (in months, 2-4, young and 20-24, old) (14).

\section{Real-time quantitative RT-PCR}

Endothelial RNA was collected by passing of $500 \mu \mathrm{l}$ guanidinium thiocyanate containing lysis solution (TriPure, Roche Applied Science) once through the aortic lumen using 22-gauge needle. Endothelial lysates from three samples were pooled (45). Total RNA isolated according to manufacturer's instructions (TriPure, Roche Applied Science). RNA concentrations were calculated by measuring the absorbance at $260 \mathrm{~nm}$. cDNA was synthesized using oligodT primers (RevertAid First Strand cDNA Synthesis Kit, Fermentas). To determine the relative expression levels of TRPC4, real-time quantitative reverse transcription polymerase chain reaction (qRT-PCR) was performed using FastStart DNA Master SYBR Green I kit and LightCycler 2.0 (Roche Applied Science). A detailed protocol was published previously (19). The primers are listed in Table I. Expression levels were normalized to that of internal $\beta$-actin $\left([\mathrm{TRPCx}] /[\beta\right.$-actin $\left.] \times 10^{4}\right)$.

\section{Western blot analysis}

Protein samples were prepared from intact thoracic aorta by homogenization in lysis solution (Camiolo buffer, $75 \mathrm{mM}$ potassium acetate, $300 \mathrm{mM} \mathrm{NaCl}, 10 \mathrm{mM}$ EDTA, $100 \mathrm{mM}$ L-arginine basic salt, and $0.25 \%$ Triton-X 100, protease inhibitor mix). Protein concentrations were determined using Bradford assay. Proteins were separated on $8 \%$ sodium dodecyl sulfate polyacrylamide gel electrophoresis and transferred to membranes (Immobilon-P polyvinylidene difluoride, Millipore) at $25^{\circ} \mathrm{C}$ for $2 \mathrm{~h}$ at $15 \mathrm{~V}$. Following 2-h blocking (with 5\% skimmed milk in Tris-buffered saline with Tween-20), membranes were incubated with TRPC4 primary antibody (1:200, Alomone Laboratories) and anti- $\beta$-actin $(1: 1,500$, Abcam Ltd.) overnight at $4{ }^{\circ} \mathrm{C}$, then with horseradish peroxidase (HRP)-conjugated goat antirabbit secondary antibody (DakoCytomation; 1:1,500) for $1 \mathrm{~h}$ at room temperature. ECL Plus Detection kit (Amersham Biosciences) was used to visualize bands, and the optical density of each blot was normalized to that of $\beta$-actin analyzed within the same lane and represented as relative optical density.

\section{Isometric force}

A detailed protocol for isolated tissue experiments was described previously (56). Briefly, rats were asphyxiated with $\mathrm{CO}_{2}$, thoracic aorta was removed and dissected into 3-mm rings. Tissues were mounted in organ chambers. After a 45-min-equilibration period, each ring was gradually stretched in $0.5-\mathrm{g}$ increments to the previously established optimal point of the resting tension $(20 \mathrm{mN})$ for rat aorta. The presence of functional endothelium was confirmed by the ACh-induced relaxations on phenylephrine (PE)-precontracted aortic rings. Tissue rings were

Table I. Oligonucleotide sequences of RT-PCR primers

\begin{tabular}{|l|c|l|c|}
\hline Gene & GenBank accession no. & \multicolumn{1}{|c|}{ Primer sequence (5'-3') } & Amplicon size, bp \\
\hline TRPC4 & NM_053434 & F: CTGCAGATATCTCTGGGAAGA & 412 \\
\hline & & R: GCTTTGTTCGAGCAAATTTCC & \\
\hline$\beta$-actin & NM_031144 & F: AGTGTGACGTTGACATCCGT & 244 \\
\hline & & R: GACTCATCGTACTCCTGCTT & \\
\hline
\end{tabular}

TRPC: transient receptor potential; F: forward; R: reverse; and bp: base pair. 
placed in organ baths containing physiological salt solution (PSS) (in $\mathrm{mM}$ : $\mathrm{NaCl}, 118 ; \mathrm{KCl}$, 4.73; $\mathrm{MgSO}_{4}, 1.2 ; \mathrm{CaNa}_{2} \mathrm{EDTA}, 0.026 ; \mathrm{NaH}_{2} \mathrm{PO}_{4}, 1.2 ; \mathrm{CaCl}_{2}, 2.5 ; \mathrm{NaHCO}_{3}, 25$; and glucose, $11,37{ }^{\circ} \mathrm{C}$ ) aerated with $95 \% \mathrm{O}_{2}-5 \% \mathrm{CO}_{2}$. All organ bath measurements were recorded with a data acquisition system (MP100, Biopac, USA). Force was normalized to cross-sectional area [force $($ in $\mathrm{mN}) /$ cross-sectional area $\left(\right.$ in $\left.\mathrm{mm}^{2}, \mathrm{~F} / \mathrm{CSA}\right)=($ change in force $\times$ circumference $) / 2 \times$ wet wt.]. Receptor-independent endothelium-derived relaxations were induced by CPA. To evaluate direct relaxing activity of vascular smooth muscle, soluble GC stimulator, an SNP was used. Both agents were added into the organ baths in a cumulative manner.

Changes in intracellular $\mathrm{Ca}^{2+}$ levels

$\left[\mathrm{Ca}^{2+}\right]_{i}$ elevations were monitored in aortic segments as described earlier (57). Briefly, vessels were inverted, deendothelialized, and mounted between two stainless-steel hooks the upper one was connected to an isometric force-displacement transducer (Kent Scientific Instruments, Litchfield, CT) attached to a displacement unit allowing a fine adjustment of tension via a micrometer. Aortic ring was gradually stretched to optimal resting tension as in the isometric force experiments, then, incubated in a glass vial for $2 \mathrm{~h}$ with $5 \mu \mathrm{M}$ fura- $2 / \mathrm{AM}$ plus $0.2 \mathrm{mM}$ neostigmine, $1 \mathrm{mM}$ probenecid, and $0.02 \%$ pluronic F-127 in PSS at room temperature in the dark. After the incubation period, the whole apparatus was mounted in a spectrophotometer cuvette and placed in a water-jacketted $\left(37^{\circ} \mathrm{C}\right)$ sample chamber of a dual-wavelength spectrofluorometer (PTI QM8/2005, Photon Technology International). The aortic segment was perfused $(12 \mathrm{ml} / \mathrm{min})$ with $37^{\circ} \mathrm{C}$ gassed PSS containing 3-mM indomethacin and $1-\mathrm{mM}$ probenecid for $30 \mathrm{~min}$ before agent addition. The intimal surface of the fura-2-loaded tissue was subjected to alternating excitation wavelengths of 340 and $380 \mathrm{~nm} / \mathrm{s}$. Intensity changes in emitted fluorescence at $510 \mathrm{~nm}$ corresponding to the ratio of $340-380 \mathrm{~nm}$ excitations $(\mathrm{F} 340 / 380)$ is reported as a relative measure of free $\left[\mathrm{Ca}^{2+}\right]_{\mathrm{i}}(57)$. For SOCE protocol, CPA is added after 5-min incubation period in $\mathrm{Ca}^{2+}$-free buffer. Following a complete CPA-induced $\mathrm{Ca}^{2+}$ transient (SR $\mathrm{Ca}^{2+}$ release), $\mathrm{Ca}^{2+}(2.5 \mathrm{mM})$ is readded to induce $\mathrm{Ca}^{2+}$ influx.

\section{Chemicals}

All chemicals were from Sigma and dissolved in appropriate solvents as given: CPA $\left(10^{-1} \mathrm{M}\right)$ in dimethylsulfoxide; $\mathrm{PE} \mathrm{HCl}\left(10^{-1} \mathrm{M}\right)$ in distilled water (DW); $\mathrm{ACh}$ $\left(10^{-1} \mathrm{M}\right)$ in DW; and SNP $\left(10^{-2} \mathrm{M}\right)$ in DW.

\section{Data analysis}

Data analysis and graphical presentations were done using GraphPad Prism5. Values of maximal effect $\left(E_{\max }\right)$ and $50 \%$ effective concentration $\left(\mathrm{EC}_{50}\right)$ were derived for each cumulative concentration-response curve using nonlinear regression analysis (GraphPad Prism 5 Software). $\mathrm{pD}_{2}$ values were calculated as $-\log \left(\mathrm{EC}_{50}\right)$. Geometric means of the $\mathrm{pD}_{2}$ values were compared. The results were given as mean \pm standard error of the mean (S.E.M.). " $n$ " represents the number of animals. The significance of differences was evaluated by Student's $t$-test. $P<0.05$ was considered significant.

\section{Results}

TRPC4 expression levels

We previously observed significant changes in TRPC1 and TRPC6 protein expression in endothelium-denuded aging rat aorta (19). Based on these data, we further hypothesized that 
TRPCs would also be differentially expressed in endothelium. Due to the limited amount of endothelial samples, endothelial RNA samples isolated from three different animals were pooled (pooled samples in duplicate). While no change was observed in vascular smooth muscle TRPC1, TRPC3, and TRPC6 mRNA levels (19), endothelial TRPC4 levels were apparently decreased in aging rat (Fig. 1A). TRPC4 protein levels significantly decreased in intact aortas of 20 to 24-month-old rats compared to that of 2-4-month-old rats (Fig. 1B; $n=3-$ $4 ; P<0.05)$.

\section{ACh- and SNP-induced endothelium-dependent relaxations}

First of all, we investigated endothelium-dependent and endothelium-independent relaxations. For this purpose, ACh and NO-donor SNP were applied in cumulative manner $\left(10^{-9}\right.$ $10^{-4} \mathrm{M}$ and $10^{-10}-10^{-6} \mathrm{M}$, respectively) on PE (300 $\mathrm{nM}$ )-contracted intact aortic rings of young and old rats. Absolute magnitude of precontraction levels (F/CSA) was similar in all cases (cumulative ACh, SNP, and CPA concentration-response curves). Consistent with previous reports, ACh maximal responses were significantly reduced with aging without affecting the sensitivity ( $\mathrm{pD}_{2}$ values) (Fig. $2 \mathrm{~A} ; n=3-4$ ). On the contrary, SNP abolished PEinduced contractions in both young and old vessels. Aging had no effect on maximal responses $\left(E_{\max }\right)$ or $\mathrm{pD}_{2}$ values of SNP (Fig. 2B; $\left.n=4-5\right)$.

\section{CPA-induced endothelium-dependent relaxations}

We further investigated the possible changes in receptor-independent endothelium-derived relaxations with aging. For this purpose, selective SERCA inhibitor CPA was applied in cumulative manner $\left(10^{-7}-10^{-5} \mathrm{M}\right)$ on PE $(300 \mathrm{nM})$-contracted intact aortic rings. $E_{\max }$ for CPA was significantly reduced without affecting the $\mathrm{pD}_{2}$ values in old rat aorta (Fig. 3, $n=3-4$, $P<0.05)$.

\section{Effects of aging on SOCE in endothelium-denuded rat aorta}

As we observed drastic decrease in TRPC4 protein levels in aging aorta, we investigated the functional consequence of changes in their expressional levels. Since CPA-induced endothelial relaxations decreased during aging, we focused on possible changes in SOCE during aging as well. Due to the experimental limitations in fura-2 loading and monitoring $\left[\mathrm{Ca}^{2+}\right]_{i}$ changes in a single layer of endothelial cells, we measured $\left[\mathrm{Ca}^{2+}\right]_{\mathrm{i}}$ changes in fura-2-loaded and endothelium-denuded rat aorta to extrapolate how aging affects SOCE. First, $10 \mu \mathrm{M} \mathrm{CPA}$
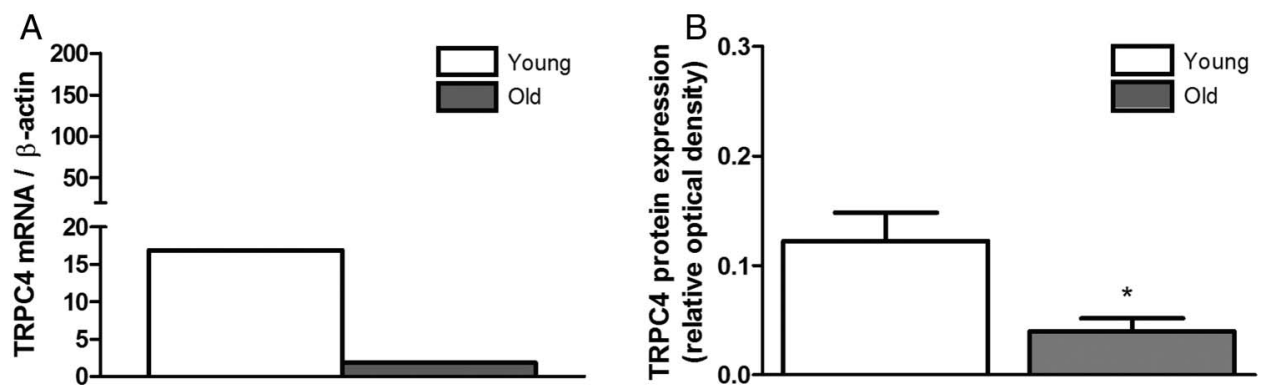

Fig. 1. Effects of aging TRPC4 expression levels. TRPC4 mRNA expression in endothelium (A, pooled samples of 3-3 animals, means of duplicates) and protein expression in intact rat aorta (B) from young and old rats $(n=3-4$, $* P<0.05)$. TRPC4: transient receptor potential canonical 4 ion channel 

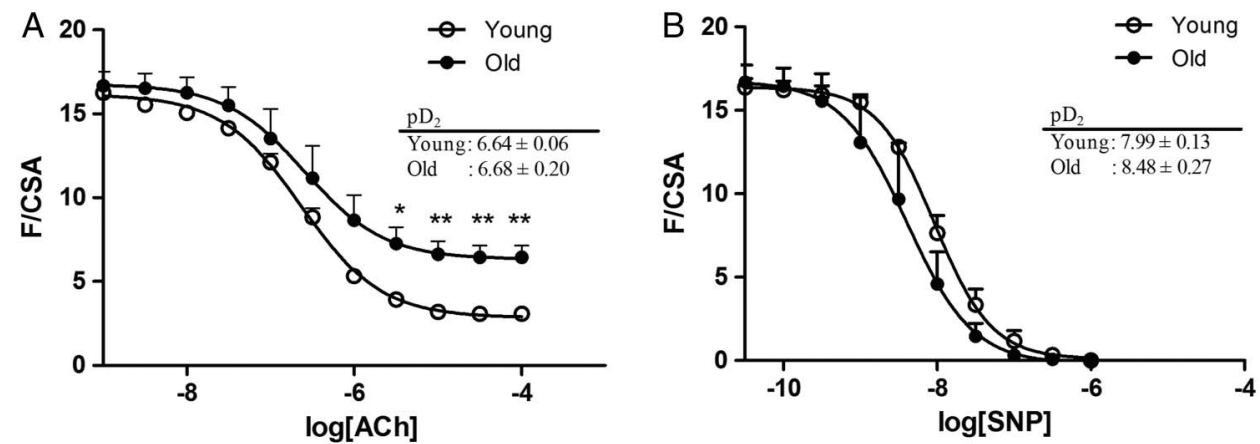

Fig. 2. Effects of aging on ACh- (A) and SNP- (B) induced relaxations. ACh $\left(10^{-9}-10^{-4} \mathrm{M}\right)$ and SNP $\left(10^{-10}\right.$ $\left.10^{-6} \mathrm{M}\right)$ concentration-response curves were obtained from PE-precontracted young $(\mathrm{o})$ and old $(\bullet)$ rat aortas. Responses are expressed as F/CSA. Data are presented as mean \pm S.E.M. $\mathrm{pD}_{2}$ values shown in the graph are means of the calculated individual $\mathrm{pD}_{2}$ values $(n=3-4$ and $n=4-5$ for $\mathrm{ACh}$ and $\mathrm{SNP}, * P<0.05 ; * * P<0.01)$. ACh: acetylcholine; SNP: sodium nitroprusside; F/CSA: force/cross-sectional area; and $\mathrm{pD}_{2}$ : negative logarithm of $50 \%$ effective concentrations of agents used

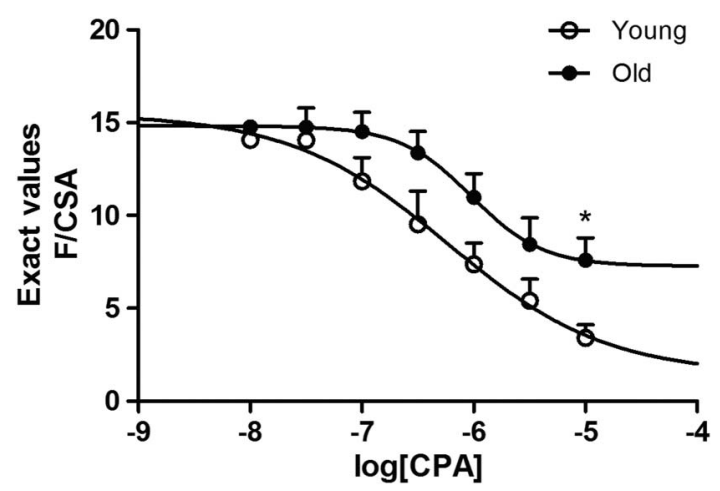

\footnotetext{
Fig. 3. Effects of aging on CPA-induced vasorelaxations. CPA $\left(10^{-7}-10^{-5} \mathrm{M}\right)$ concentration-response curves obtained from PE-precontracted young (o) and old $(\bullet)$ rat aortas. Responses are expressed as F/CSA. Data are presented as mean \pm S.E.M. Average $\mathrm{pD}_{2}$ values are means of the calculated individual $\mathrm{pD}_{2}$ values $(n=3-4, * P<0.05)$. CPA: cyclopiazonic acid; PE: phenylephrine; $\mathrm{F} / \mathrm{CSA}$ : force/cross-sectional area; and $\mathrm{pD}_{2}$ : negative logarithm of $50 \%$ effective concentrations of agents used
}

was added in the absence of $\mathrm{Ca}^{2+}$. Then, re-addition of $1.5 \mathrm{mM} \mathrm{Ca}^{2+}$ elevated amplitude of fura-2 signal. SR $\mathrm{Ca}^{2+}$ release was not affected by aging (Fig. $4 \mathrm{~A}$ and $\mathrm{C}$ ). On the other hand, CPA-induced SOCE significantly decreased in old rat aorta (Fig. 4B and C; $n=3-4 ; P<0.01$ ).

\section{Discussion}

The present study shows that TRPC4 protein that was suggested to be responsible for SOCE (10) in endothelium, decreased in intact rat aorta during aging. The downregulation of endothelium-dependent $\mathrm{ACh}$-induced relaxations in rat thoracic aorta during aging observed in our study is consistent with the previous reports $(8,14,25,37,38)$. In addition to the ACh responses, we observed that CPA-induced (receptor independent) endothelial relaxations were also decreased in aorta from old rats. On the other hand, SNP-induced vasorelaxations did not change suggesting that downstream of endothelium-derived relaxing mechanisms are not affected by aging. In addition to the attenuated ACh and CPA responses, SOCE induced by SERCA inhibition in endothelium-denuded rat aorta was also decreased. The 


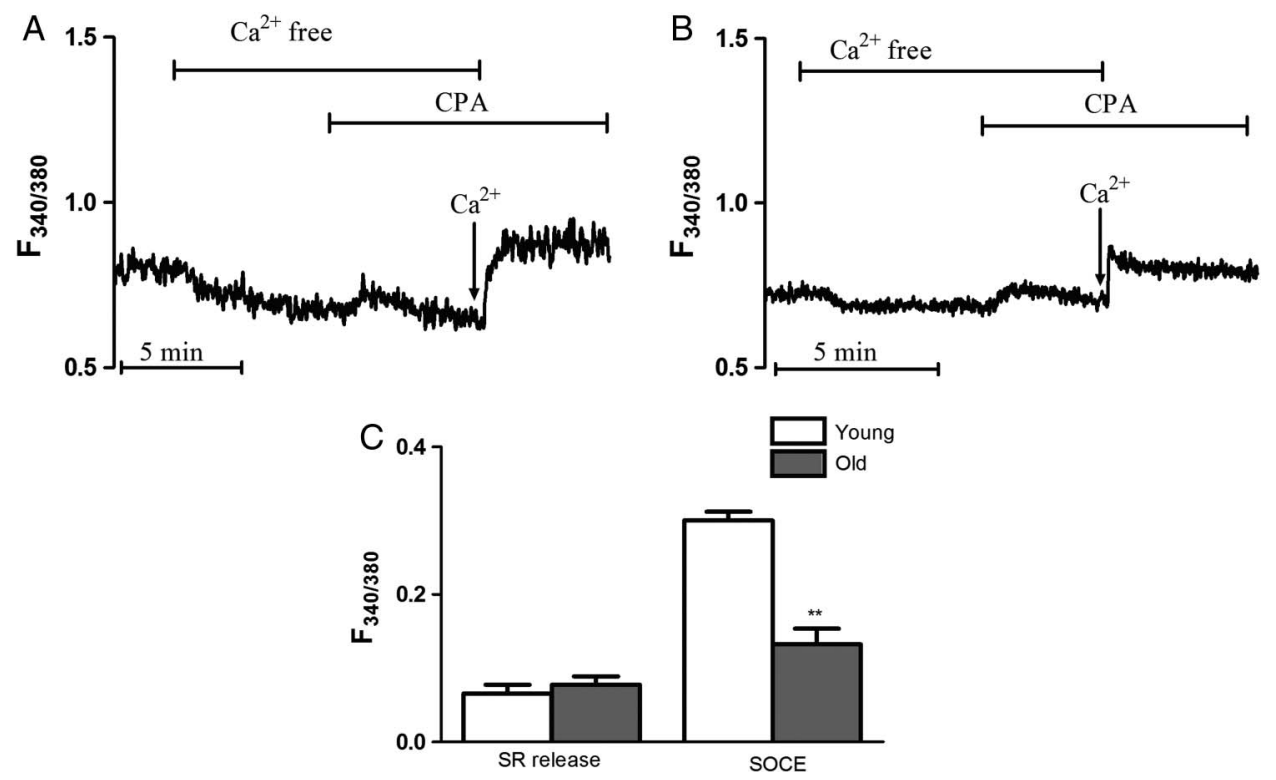

Fig. 4. Effects of aging on SR Ca ${ }^{2+}$ release and SOCE. Steady-state $\left[\mathrm{Ca}^{2+}\right]_{\mathrm{i}}$ elevation was assessed by the addition of $2.5 \mathrm{mM} \mathrm{Ca}^{2+}$ following $10 \mu \mathrm{M} \mathrm{CPA}$ treatment. Representative tracings obtained from young (A) and old (B) rat thoracic aorta and the mean $\left( \pm\right.$ S.E.M.) values $(n=3-4, * * P<0.01)$ of plateau fura-2 signals after $\mathrm{Ca}^{2+}$ readdition

(C) are shown. SR: sarcoplasmic reticulum; SOCE: store-operated $\mathrm{Ca}^{2+}$ entry; and CPA: cyclopiazonic acid

downregulated SOCE might be resulted from a proportional loss of TRPC1 during aging as observed in our previous study (19).

As endothelium is crucially important in the regulation of vascular smooth muscle tone through several endothelium-derived relaxing and contracting factors, any imbalance between these factors results in endothelial dysfunction. Although different hypotheses have been postulated for age-related endothelial dysfunction mechanism $(8,11,14,23,25,32)$, the exact mechanism has not been clarified yet. Contradictory data exist on age-related changes on eNOS expression and NO production such that some show downregulation $(5,14,52,58)$, while others suggest upregulation $(22,60)$. Furthermore, increased production of reactive oxygen species were also reported during aging $(14,24,27,48,60)$. Enhanced production of vasoconstricting factors also contributes to age-related endothelial dysfunction $(5,37,38)$. In the present study, CPA-induced vasorelaxations were also decreased suggesting that receptor-independent signal transduction mechanisms also contribute to the endotheliumdependent changes during aging. Since SOCE is activated by SR depletion following both ACh-induced $\mathrm{IP}_{3}$ production and CPA-induced SERCA inhibition (41), decreased SOCE may contribute to the age-related endothelial dysfunction $(34,36)$. In addition to these, the essential component of endothelium-dependent relaxations of vascular smooth muscle cells (34), TRPC4 was decreased (present study) with aging. A number of studies have demonstrated the role of TRPCs in SOCE and vascular function $(20,41,55)$. For example, in TRPC4 ${ }^{-/}$mice, store-operated $\mathrm{Ca}^{2+}$ current decreased in endothelial cells, resulting in impaired endothelial vasodilatation (20). It was also demonstrated that decreases in TRPC4 protein levels following the endothelial denudation in rat cerebral arteries is consistent with its predominant endothelial localization (6). Bergdahl et al. have also suggested that expression of TRPC4 is well correlated 


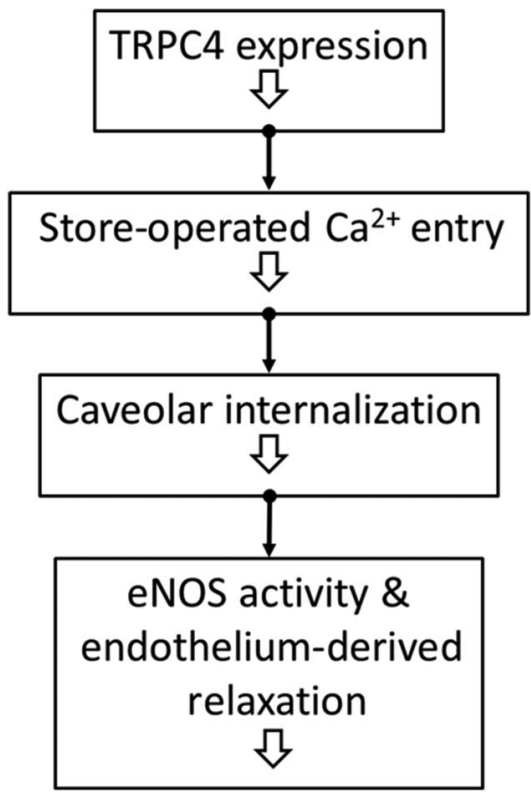

Fig. 5. The model summarizing the overall effects of TRPC4 downregulation in aging rat aorta. The model depicts that any decrease in TRPC4 expression is reflected as impaired $\mathrm{Ca}^{2+}$ entry through SOCs (see the section "Discussion" for details) eventually leading to endothelial dysfunction. TRPC4: C4 type transient receptor potential ion channel

with the amount of endothelium present in intact arteries (6). Because of the profound presence of TRPC4 in endothelium, the age-related decreases in TRPC4 protein expression observed in intact rat thoracic aorta may result from attenuated endothelial TRPC4 protein expression. Although the data did not yield a statistical significance, decreased endothelial TRPC4 mRNA expression during aging is consistent with our western blot data.

In the present study, CPA-induced SOCE amplitude decreased in endothelium-denuded rat aorta with aging. Based on our previous data, TRPC1 protein levels decreased significantly whereas that of TRPC6 increased during aging (19). Similar to the present results, SOCE has been shown to be decreased in mouse skeletal muscle during aging $(18,54)$. Furthermore, downregulation of TRPC1 protein by an antisense oligonucleotide also decreased SOC currents (51). As summarized in Fig. 5, it can be proposed that downregulation of TRPC4 (possibly along with TRPC1) deregulates SOC assembly and related $\mathrm{Ca}^{2+}$ influx in caveolar microdomains of endothelial cells precluding the removal of tonic inhibitory effect of Cav-1 on eNOS activity via preventing caveolar detachment or internalization. In conclusion, age-related downregulation of TRPC channels may impair endothelium-derived relaxations and even worsen the existing vasospasm.

\section{Acknowledgements}

This work was supported by The Scientific and Technological Research Council of Turkey (TUBITAK, 103 S176 to MT) and partially by Ege University Research Projects (EBILTEM-05BIL016 and BAP-04ECZ011 to MT).

\section{REFERENCES}

1. Abdullaev IF, Bisaillon JM, Potier M, Gonzalez JC, Motiani RK, Trebak M: Stim1 and Orail mediate CRAC currents and store-operated calcium entry important for endothelial cell proliferation. Circ. Res. 103, 1289-1299 (2008) 
2. Albert AP, Saleh SN, Large WA: Identification of canonical transient receptor potential (TRPC) channel proteins in native vascular smooth muscle cells. Curr. Med. Chem. 16, 1158-1165 (2009)

3. Ambudkar IS: $\mathrm{Ca}^{2+}$ signaling microdomains: platforms for the assembly and regulation of TRPC channels. Trends Pharmacol. Sci. 27, 25-32 (2006)

4. Atkinson J: Age-related medial elastocalcinosis in arteries: mechanisms, animal models, and physiological consequences. J. Appl. Physiol. 105, 1643-1651 (2008)

5. Barton M, Cosentino F, Brandes RP, Moreau P, Shaw S, Luscher TF: Anatomic heterogeneity of vascular aging: role of nitric oxide and endothelin. Hypertension 30, 817-824 (1997)

6. Bergdahl A, Gomez MF, Wihlborg AK, Erlinge D, Eyjolfson A, Xu SZ, Beech DJ, Dreja K, Hellstrand P: Plasticity of TRPC expression in arterial smooth muscle: correlation with store-operated $\mathrm{Ca}^{2+}$ entry. Am. J. Physiol. Cell Physiol. 288, C872-C880 (2005)

7. Berra-Romani R, Mazzocco-Spezzia A, Pulina MV, Golovina VA: $\mathrm{Ca}^{2+}$ handling is altered when arterial myocytes progress from a contractile to a proliferative phenotype in culture. Am. J. Physiol. Cell Physiol. 295, C779-C790 (2008)

8. Brandes RP, Fleming I, Busse R: Endothelial aging. Cardiovasc. Res. 66, 286-294 (2005)

9. Brotto M: Aging, sarcopenia and store-operated calcium entry: a common link? Cell Cycle 10, 4201-4202 (2011)

10. Cheng KT, Ong HL, Liu X, Ambudkar IS: Contribution and regulation of TRPC channels in store-operated $\mathrm{Ca}^{2+}$ entry. Curr. Top. Membr. 71, 149-179 (2013)

11. Chou TC, Yen MH, Li CY, Ding YA: Alterations of nitric oxide synthase expression with aging and hypertension in rats. Hypertension 31, 643-648 (1998)

12. Cogolludo AL, Perez-Vizcaino F, Zaragoza-Arnaez F, Ibarra M, Lopez-Lopez G, Lopez-Miranda V, Tamargo J: Mechanisms involved in SNP-induced relaxation and $\left[\mathrm{Ca}^{2+}\right]_{i}$ reduction in piglet pulmonary and systemic arteries. Br. J. Pharmacol. 132, 959-967 (2001)

13. Corbi G, Conti V, Russomanno G, Rengo G, Vitulli P, Ciccarelli AL, Filippelli A, Ferrara N: Is physical activity able to modify oxidative damage in cardiovascular aging? Oxid. Med. Cell Longev. 2012, 728547 (2012)

14. Csiszar A, Ungvari Z, Edwards JG, Kaminski P, Wolin MS, Koller A, Kaley G: Aging-induced phenotypic changes and oxidative stress impair coronary arteriolar function. Circ. Res. 90, 1159-1166 (2002)

15. Davis MJ, Hill MA: Signaling mechanisms underlying the vascular myogenic response. Physiol. Rev. 79, 387423 (1999)

16. del Corsso C, Ostrovskaya O, McAllister CE, Murray K, Hatton WJ, Gurney AM, Spencer NJ, Wilson SM: Effects of aging on $\mathrm{Ca}^{2+}$ signaling in murine mesenteric arterial smooth muscle cells. Mech. Ageing Dev. 127, 315-323 (2006)

17. Dietrich A, Chubanov V, Kalwa H, Rost BR, Gudermann T: Cation channels of the transient receptor potential superfamily: their role in physiological and pathophysiological processes of smooth muscle cells. Pharmacol. Ther. 112, 744-760 (2006)

18. Edwards JN, Blackmore DG, Gilbert DF, Murphy RM, Launikonis BS: Store-operated calcium entry remains fully functional in aged mouse skeletal muscle despite a decline in STIM1 protein expression. Aging Cell 10, 675-685 (2011)

19. Erac Y, Selli C, Kosova B, Akcali KC, Tosun M: Expression levels of TRPC1 and TRPC6 ion channels are reciprocally altered in aging rat aorta: implications for age-related vasospastic disorders. Age (Dordr) 32, 223230 (2010)

20. Freichel M, Suh SH, Pfeifer A, Schweig U, Trost C, Weissgerber P, Biel M, Philipp S, Freise D, Droogmans G, Hofmann F, Flockerzi V, Nilius B: Lack of an endothelial store-operated $\mathrm{Ca}^{2+}$ current impairs agonist-dependent vasorelaxation in TRP4 ${ }^{-/-}$mice. Nat. Cell Biol. 3, 121-127 (2001)

21. Garcia-Cardena G, Martasek P, Masters BS, Skidd PM, Couet J, Li S, Lisanti MP, Sessa WC: Dissecting the interaction between nitric oxide synthase (NOS) and caveolin. Functional significance of the NOS caveolin binding domain in vivo. J. Biol. Chem. 272, 25437-25440 (1997)

22. Goettsch W, Lattmann T, Amann K, Szibor M, Morawietz H, Munter K, Muller SP, Shaw S, Barton M: Increased expression of endothelin-1 and inducible nitric oxide synthase isoform II in aging arteries in vivo: implications for atherosclerosis. Biochem. Biophys. Res. Commun. 280, 908-913 (2001)

23. Gryglewski RJ, Palmer RM, Moncada S: Superoxide anion is involved in the breakdown of endothelium-derived vascular relaxing factor. Nature 320, 454-456 (1986)

24. Hamilton CA, Brosnan MJ, McIntyre M, Graham D, Dominiczak AF: Superoxide excess in hypertension and aging: a common cause of endothelial dysfunction. Hypertension 37, 529-534 (2001)

25. Heymes C, Habib A, Yang D, Mathieu E, Marotte F, Samuel J, Boulanger CM: Cyclo-oxygenase-1 and -2 contribution to endothelial dysfunction in ageing. Br. J. Pharmacol. 131, 804-810 (2000) 
26. Inoue R, Jian Z, Kawarabayashi Y: Mechanosensitive TRP channels in cardiovascular pathophysiology. Pharmacol. Ther. 123, 371-385 (2009)

27. Jacobson A, Yan C, Gao Q, Rincon-Skinner T, Rivera A, Edwards J, Huang A, Kaley G, Sun D: Aging enhances pressure-induced arterial superoxide formation. Am. J. Physiol. Heart Circ. Physiol. 293, H1344-H1350 (2007)

28. Jeong SM, Lee JH, Kim S, Rhim H, Lee BH, Kim JH, Oh JW, Lee SM, Nah SY: Ginseng saponins induce storeoperated calcium entry in Xenopus oocytes. Br. J. Pharmacol. 142, 585-593 (2004)

29. Ju H, Zou R, Venema VJ, Venema RC: Direct interaction of endothelial nitric-oxide synthase and caveolin-1 inhibits synthase activity. J. Biol. Chem. 272, 18522-18525 (1997)

30. Kan H, Ruan Y, Malik KU: Signal transduction mechanism(s) involved in prostacyclin production elicited by acetylcholine in coronary endothelial cells of rabbit heart. J. Pharmacol. Exp. Ther. 282, 113-122 (1997)

31. Karavidas A, Lazaros G, Tsiachris D, Pyrgakis V: Aging and the cardiovascular system. Hellenic J. Cardiol. 51, 421-427 (2010)

32. Kovacic JC, Moreno P, Nabel EG, Hachinski V, Fuster V: Cellular senescence, vascular disease, and aging: part 2 of a 2-part review: clinical vascular disease in the elderly. Circulation 123, 1900-1910 (2011)

33. Kuriyama H, Kitamura K, Itoh T, Inoue R: Physiological features of visceral smooth muscle cells, with special reference to receptors and ion channels. Physiol. Rev. 78, 811-920 (1998)

34. Kwan HY, Huang Y, Yao X: TRP channels in endothelial function and dysfunction. Biochim. Biophys. Acta 1772, 907-914 (2007)

35. Kwiatek AM, Minshall RD, Cool DR, Skidgel RA, Malik AB, Tiruppathi C: Caveolin-1 regulates store-operated $\mathrm{Ca}^{2+}$ influx by binding of its scaffolding domain to transient receptor potential channel-1 in endothelial cells. Mol. Pharmacol. 70, 1174-1183 (2006)

36. Leung FP, Yung LM, Yao X, Laher I, Huang Y: Store-operated calcium entry in vascular smooth muscle. Br. J. Pharmacol. 153, 846-857 (2008)

37. Matz RL, de Sotomayor MA, Schott C, Stoclet JC, Andriantsitohaina R: Vascular bed heterogeneity in agerelated endothelial dysfunction with respect to NO and eicosanoids. Br. J. Pharmacol. 131, 303-311 (2000)

38. Matz RL, Schott C, Stoclet JC, Andriantsitohaina R: Age-related endothelial dysfunction with respect to nitric oxide, endothelium-derived hyperpolarizing factor and cyclooxygenase products. Physiol. Res. 49, 11-18 (2000)

39. Norwood N, Moore TM, Dean DA, Bhattacharjee R, Li M, Stevens T: Store-operated calcium entry and increased endothelial cell permeability. Am. J. Physiol. Lung Cell Mol. Physiol. 279, L815-L824 (2000)

40. Parekh AB, Putney JW Jr: Store-operated calcium channels. Physiol. Rev. 85, 757-810 (2005)

41. Philipp S, Trost C, Warnat J, Rautmann J, Himmerkus N, Schroth G, Kretz O, Nastainczyk W, Cavalie A, Hoth M, Flockerzi V: TRP4 (CCE1) protein is part of native calcium release-activated $\mathrm{Ca}^{2+}$-like channels in adrenal cells. J. Biol. Chem. 275, 23965-23972 (2000)

42. Potier M, Gonzalez JC, Motiani RK, Abdullaev IF, Bisaillon JM, Singer HA, Trebak M: Evidence for STIM1and Orail-dependent store-operated calcium influx through ICRAC in vascular smooth muscle cells: role in proliferation and migration. FASEB J. 23, 2425-2437 (2009)

43. Putney JW Jr: TRP, inositol 1, 4, 5-trisphosphate receptors, and capacitative calcium entry. Proc. Natl. Acad. Sci. U S A 96, 14669-14671 (1999)

44. Selli C, Erac Y, Tosun M: Cyclopiazonic acid alters serotonin-induced responses in rat thoracic aorta. Vasc. Pharmacol. 61, 43-48 (2014)

45. Simon AM, McWhorter AR: Decreased intercellular dye-transfer and downregulation of non-ablated connexins in aortic endothelium deficient in connexin37 or connexin40. J. Cell Sci. 116, 2223-2236 (2003)

46. Sowa G: Caveolae, caveolins, cavins, and endothelial cell function: new insights. Front. Physiol. 2, 120 (2012)

47. Stiber J, Hawkins A, Zhang ZS, Wang S, Burch J, Graham V, Ward CC, Seth M, Finch E, Malouf N, Williams RS, Eu JP, Rosenberg P: STIM1 signalling controls store-operated calcium entry required for development and contractile function in skeletal muscle. Nat. Cell Biol. 10, 688-697 (2008)

48. Sun D, Huang A, Yan EH, Wu Z, Yan C, Kaminski PM, Oury TD, Wolin MS, Kaley G: Reduced release of nitric oxide to shear stress in mesenteric arteries of aged rats. Am. J. Physiol. Heart Circ. Physiol. 286, H2249-H2256 (2004)

49. Sundivakkam PC, Freichel M, Singh V, Yuan JP, Vogel SM, Flockerzi V, Malik AB, Tiruppathi C: The Ca(2+) sensor stromal interaction molecule 1 (STIM1) is necessary and sufficient for the store-operated $\mathrm{Ca}(2+)$ entry function of transient receptor potential canonical (TRPC) 1 and 4 channels in endothelial cells. Mol. Pharmacol. $81,510-526$ (2012)

50. Sundivakkam PC, Kwiatek AM, Sharma TT, Minshall RD, Malik AB, Tiruppathi C: Caveolin-1 scaffold domain interacts with TRPC1 and IP3R3 to regulate $\mathrm{Ca}^{2+}$ store release-induced $\mathrm{Ca}^{2+}$ entry in endothelial cells. Am. J. Physiol. Cell Physiol. 296, C403-C413 (2009) 
51. Sweeney M, Yu Y, Platoshyn O, Zhang S, McDaniel SS, Yuan JX: Inhibition of endogenous TRP1 decreases capacitative $\mathrm{Ca}^{2+}$ entry and attenuates pulmonary artery smooth muscle cell proliferation. Am. J. Physiol. Lung Cell Mol. Physiol. 283, L144-L155 (2002)

52. Tanabe T, Maeda S, Miyauchi T, Iemitsu M, Takanashi M, Irukayama-Tomobe Y, Yokota T, Ohmori H, Matsuda M: Exercise training improves ageing-induced decrease in eNOS expression of the aorta. Acta Physiol. Scand. 178, 3-10 (2003)

53. Targos B, Barańska J, Pomorski P: Store-operated calcium entry in physiology and pathology of mammalian cells. Acta Biochim. Pol. 52, 379-409 (2005)

54. Thornton AM, Zhao X, Weisleder N, Brotto LS, Bougoin S, Nosek TM, Reid M, Hardin B, Pan Z, Ma J, Parness J, Brotto M: Store-operated $\mathrm{Ca}(2+)$ entry (SOCE) contributes to normal skeletal muscle contractility in young but not in aged skeletal muscle. Aging (Albany NY) 3, 621-634 (2011)

55. Tiruppathi C, Freichel M, Vogel SM, Paria BC, Mehta D, Flockerzi V, Malik AB: Impairment of store-operated $\mathrm{Ca}^{2+}$ entry in TRPC4(-/-) mice interferes with increase in lung microvascular permeability. Circ. Res. 91, 70-76 (2002)

56. Tosun M, Erac Y, Selli C, Karakaya N: Sarcoplasmic-endoplasmic reticulum $\mathrm{Ca}^{2+}$-ATPase inhibition prevents endothelin A receptor antagonism in rat aorta. Am. J. Physiol. Heart Circ. Physiol. 292, H1961-1966 (2006)

57. Tosun M, Paul RJ, Rapoport RM: Coupling of store-operated $\mathrm{Ca}^{++}$entry to contraction in rat aorta. J. Pharmacol. Exp. Ther. 285, 759-766 (1998)

58. Tschudi MR, Barton M, Bersinger NA, Moreau P, Cosentino F, Noll G, Malinski T, Luscher TF: Effect of age on kinetics of nitric oxide release in rat aorta and pulmonary artery. J. Clin. Invest. 98, 899-905 (1996)

59. Ungvari Z, Kaley G, de Cabo R, Sonntag WE, Csiszar A: Mechanisms of vascular aging: new perspectives. J. Gerontol. A Biol. Sci. Med. Sci. 65, 1028-1041 (2010)

60. van der Loo B, Labugger R, Skepper JN, Bachschmid M, Kilo J, Powell JM, Palacios-Callender M, Erusalimsky JD, Quaschning T, Malinski T, Gygi D, Ullrich V, Luscher TF: Enhanced peroxynitrite formation is associated with vascular aging. J. Exp. Med. 192, 1731-1744 (2000)

61. Watanabe H, Murakami M, Ohba T, Takahashi Y, Ito H: TRP channel and cardiovascular disease. Pharmacol. Ther. 118, 337-351 (2008) 